\title{
LAW ENFORCERS RECOGNITION LEVEL EMERGING THREATS BASED ON PHYSICAL APPEARANCE AND BEHAVIOR SIGNS THE ENEMY
}

Radzievskiy R.M., Plisko V.I.

Chernigov National Pedagogical University

\begin{abstract}
Annotation. Purpose: examine the effectiveness of the training method of differential approach to the choice of means of influence on the action of law enforcers opponent with different levels of aggressiveness. Material: the experiment involved 15 students of the Kyiv National Academy of Internal Affairs and the 15 employees of the State Guard of Ukraine. Results: presented curriculum for special physical and tactical training. The program details the conceptual apparatus of THREATS and DANGERS manifestations of different levels of aggressiveness opponent (case analysis of its motor behavior). The study participants underwent 7 day course focused training. The basis of the course is an advanced theoretical base. The base is aimed at developing knowledge and skills of employees in determining the level of danger. Including threats from testing and modeling episodes of extreme situations the options cadets. Conclusions: In the simulated collision situations with aggressive opponent to the students significantly improved the adequacy of the response to the threat of execution time and within the legal grounds. Recognition was determined by the level of aggressiveness manifest manners enemy, his emotions, motivation, motor behavior, positional arrangement for 2 - 3 seconds. The program contributed to the development of qualities: attention, orientation, perception, motor lead.
\end{abstract}

Keywords: law enforcement, enemy, choice of actions, motor behavior, aggression, danger, threat.

\section{Introduction}

Analysis of law officers' functioning in condition of fight with adversary showed their relatively weak fitness for such situation. Rather often wrong decisions, incomplete understanding of situation, in respect to different levels of threat result, in law officers' inadequate response that, in its turn, leads to problem of uncompleted conflict.

As a result law officer are often wounded, receive different traumas or, on the contrary, are brought to justice for exceeding limits of physical influence, resulting in legal consequences. The mentioned by us problem shows at importance of its decision because it concerns law officers' resistance to different dangers.

In the course of our research we found the problem of weak self-identification by law officers in such situations and the sense of this problem is that physical education and special-tactic academic programs do not include such directions as mastering of knowledge and skills in recognition of threats, dangers by a number of behavior, external motion signs of adversary.

Analysis of works, fulfilled by specialists in professional training of law officers showed their one-side approach to solution of studied problems. For example, in field of special physical training they are regarded in respect of development of own special, physical and mental qualities, without training of skills in perception and evaluation of external threats and dangers (Anufriyev M.I., Babenko V.G. [9], Bondarenko V.V. [13], Bulachek V.R. [6], Butov S. Ye., Viniarchuk I.S., Gida O.F. [8], Yosypiv Yu.R., Zakorko I.P. [10], Popov O.V., Reshko S.M., Yanko I.V., Belur J. и соавторы [21], Dean G. et al. [22], Heinonen A. et al. [25], Royds D. [26], Ryan B.J. [27], Semukhina O. [28], Thomassen G. [29], Walker S. [30]).

In the same way psychologists (Shoygu Yu.S. [7], Gurenkova T.N., Smirnov B.A., Dolgopolova Ye.V. [11], Yevsiukov O.P. [12], Liefterov O.V. [14]) do not give any estimation of motion responses to danger. Like jurists (Artamanova G.K. [15], Kartashov V.N. [16], Kazakov Yu.N. [17], Derkach A.A., Zazykin V.G. [18], Dmytrenko I.A. [19], Atrekozov V.G. [20]; Dean G., Fahsing I.A., Gottschalk P. [23]; Glomseth R., Gottschalk P., Solli-Sæther H. [24]), give recommendations for already happened situations in compliance with clauses of criminal code.

At the same time the moment of fight with armed (aggressive) adversary is still important for law officer, especially his ability to very quickly (during 2-3 seconds) evaluate situation and take decision what to do. Also it is important to timely respond to adversary with minimal risk for himself and other people, functioning in legal field.

The mentioned requirements can be defined as insufficiently solved problem. That is why it requires new approaches to working out of more perfect methodic for law officers' professional training.

Purpose, tasks of the work, material and methods

The purpose of this article is to analyze law officers' functioning in choosing adequate to danger or threat means. The tasks:

1. Studying, analyzing and widening of theoretical part of law officers' training for different conditions, connected with threats and danger.

2. To experimentally ground effectiveness of training for determination of threats' motion signs.

Main experiment was carried out with cadets ( $n-30$ человек) of Kyiv National academy of home affairs as well as with military officers of Governmental security of Ukraine (Kyiv). For testing of data, received in theoretical part we used pedagogic testing and simulation of extreme situation by method of scientific experiment.

Mathematical processing of results of the research permitted to determine a number of indicators, which facilitate strengthening of law officers' fitness.

\footnotetext{
(c) Radzievskiy R.M., Plisko V.I., 2015

http://dx.doi.org/10.15561/20755279.2015.0108
} 


\section{Results of the research}

Training of cadets for positive solution of conflict situations with aggressive adversary requires knowledge about their typical character, multiplicity of variants, conditions, with which they can meet in reality. And in compliance with virtual situation cadets shall be able to compare own abilities to fulfill tasks in conditions of different threats. So it was necessary to form ability to determine the level of sudden threat as quick as possible and adequately respond to it.

Manifestation of sudden threat usually takes from 1 to 3 seconds. It is difficult to train law officers to adequately respond to such threat during so short period and to form their appropriate skills. Every non standard situation has own specific signs of threat. It is necessary to determine these signs by adversary's behavior or movements and create general algorithm with certain deviations with certain parameters. Training process shall not be reduced to seeking of regularities and their determination shall be realized by typical signs of one or another threat considering sense of time.

In working out of modern methodic the newest is formation of skills to determine one or another threat in minimal time with simultaneous responding to it [1].

It should be realized that this methodic does not include threats of natural disasters, fires and so on. In this methodic only subject-to-subject functioning is regarded. With it one should differentiate defense of law officer's safety and defense of human right of a person with, whom law officer comes in contact, fulfilling his duties.

Special course of cadets' training to realize threat or danger is conducted in compliance with corrected program in several stages: 1) mastering of theory; 2) formation of ability to percept situation in the whole; 3) formation of knowledge about motion behavior and other signs of adversary; 4) choosing of actions in conditions of simulated situations. To effectively act in practice it is necessary, first of all, to open sense of main variants of actions, their characteristics [5]. We understand general idea in the following way:

Movements are purposeful and forced manifestation of human motion functioning, conditioned by fulfillment of certain tasks depending on purposes and environment;

Motion functioning - is level of manifestation of motion abilities and skills;

Sense-situational task - is mentally realized and consciously taken decision about fulfillment of purposeful movements in compliance with situation, considering safety of these movements and their efficiency and legal character;

Motion task - is requirement to fulfill certain movements with pre-set bio-mechanical characteristics for achievement of target;

Situational action - is manifestation of sense and motion functioning of a person, directed to seeking of solution of certain situational task;

Control - (informational-psychological structure) is ensured by such functional activity of nervous system, which results in formation of person's motive and target of action. On the base of processing of information about environment operative image of action is constructed (conceptual model), decision is taken, check up of results and correction of functioning is fulfilled.

Threat shall be understood as such behavior of adversary, which, by its characteristics, can bring potential or direct risk for health and life of law officers and other people.

To determine actions by level of threat, level of danger and conditions of their appearing it is necessary to base on general definitions.

Manifestations of levels of threat are as follows: obvious, potential, hidden, spontaneous, absence of threat.

Obvious threat - is registered adversary's physical actions directed against law officer or other person (including action, which can result in irreversible after effects).

Potential threat - is demonstrative aggressive behavior of armed (not armed) adversary without attempts to realize threat in practice. But in case of non-professional behavior of law officer this threat can become obvious (come in previous rank).

Hidden threat: with general tension in subject's behavior aggressiveness is not visible, flexibility is possible. But in specific conditions risk of attack is not excluded.

Indirect threat behavior and actions are not aggressive, but with it they are not controlled. Confusion can be caused by appearing of law officer. Avoiding from contact with law officer is possible.

Spontaneous threat - is uncontrolled behavior of some group, which can cause violation of public order.

Absence of threat is character of situational events between law officers and people, who manifest no threat (though situation is tensed).

Levels of danger are as following: high, middle, low and absence of danger.

High level: situational actions with high dynamic, oriented on traumatizing of vital human organs.

Middle level: physical actions, which can result in serious damage of functionally important human organs.

Low level: physical efforts as a response to external counter action and which can not damage human organs or parts of body.

Absence of danger: in conditions of tensed situation there are no pre conditions to any physical actions or counter actions. analysis:

Besides, the trainees were offered main characteristics of preparatory and attacking actions, as well as their

- Kinds of actions: attacks, counter actions, hidden-aggressive, provoked, neutral. 
- Attacks: initial aggressive physical actions with application of different objects, with clear amplitude of movements and which are directed to damaging of certain target.

- Counter actions: physical resistance with different amplitude of movements, with the help and without help of objects in response to actions of "irritator".

- Hidden-aggressive actions, with which amplitude of actions does not point at any aggressiveness. But in favorable conditions of situation there can appear aggressive action directed to achievement of target.

- Provoked actions are motion response to behavior of "irritator" with inadequate manners.

- Neutral actions: actions with character of expectation without any aggressiveness (though in tensed situation).

Means of attack: actions with clear amplitude of movements (straight, from side, from back); actions with hidden amplitude of actions (straight, from side, from back); with different objects and different angles of attack.

Characteristics of attack with clear amplitude of movements are the following: preparatory actions; movements with object (weapon); angle and direction of trajectory of threatening movement by temp, speed, inadequacy, purposefulness. Attack can be from the spot, in walking, frontal or from back, from side. With it direction of adversary's motion can be different.

Characteristics of attacking movements with hidden amplitude: preparatory movements do ot show possible attack, presence of any object in hand or its seizing is not visible, distance to targe6t can be rather short. Movements are fulfilled mainly from the spot in one direction.

After familiarizing with general conceptions on this topic the trainees shall enlarge knowledge on specificity of actions' manifestation, their determination, purposefulness, their legal limits and responsibility. It will permit to evaluate actions themselves in differentiated way.

Constructions of diagrams - models significantly deepen sense order of threats and dangers. It significantly enriches theoretical part of special training course.

For holistic perception of actions in extreme conditions the trainees were offered schematic models, their variant by levels of threat, danger, by means of their realization (see figs. 1,2).

Analysis of every component in the proposed diagrams give trainees better understanding of interconnections between behavioral characteristics, environment and situational conditions, in compliance with danger's or threat's level.

One of methods of threat's (danger) recognition by law officer is his ability to percept situation. In its base there is working out of certain skills.

Perception of situation is an informational-analytical process, in which system of analyzers and receptors of a person play important role. Such qualities as attention and power of observation help to manifestation of threat even during 1 second. It permits to timely respond to direct threat. With sudden situational threat visual analyzer restricts perception of space; all attention is directed to danger. It substantially hinders from objective and tactic analysis of situation. Adaptation (habit) can be formed in conditions of constant trainings, in which formation of skills goes simultaneously with analysis of threat's level and environment.

It pre conditions further actions of law officer. It is purposeful to train visual analyzer without using of other analyzers (in such conditions visual resource increases). In practice, in conditions of darkness or twilight healing analyzer is engaged to larger extent. . With developed (trained) hearing analyzer there is opportunity to distinguish kind of arm, with which shot was fulfilled, or other sounds (resembling shots).

Undoubtedly, positive result is achieved with ability to be ahead of adversary, resulted from recognition of threat [3]. For this purpose one shall have knowledge about adversary's behavior and act selectively (in the frames of legal field). Acquiring of knowledge of main space-time motion parameters, characteristics and manner of adversary's behavior will permit to accentuate attention on development of qualities, which can ensure motion domination. The acquired motion skills permit to quicker orient in situation by time, to recognize obstacles and prognosticate actions. With respect to adversary's actions behavior can be: motivational, aggressive, forcing, defensive, expressive. In specialists' opinion, there can be no previously planned crimes without motives. But by mentality not every person is able to shoot and kill other person [3]. 


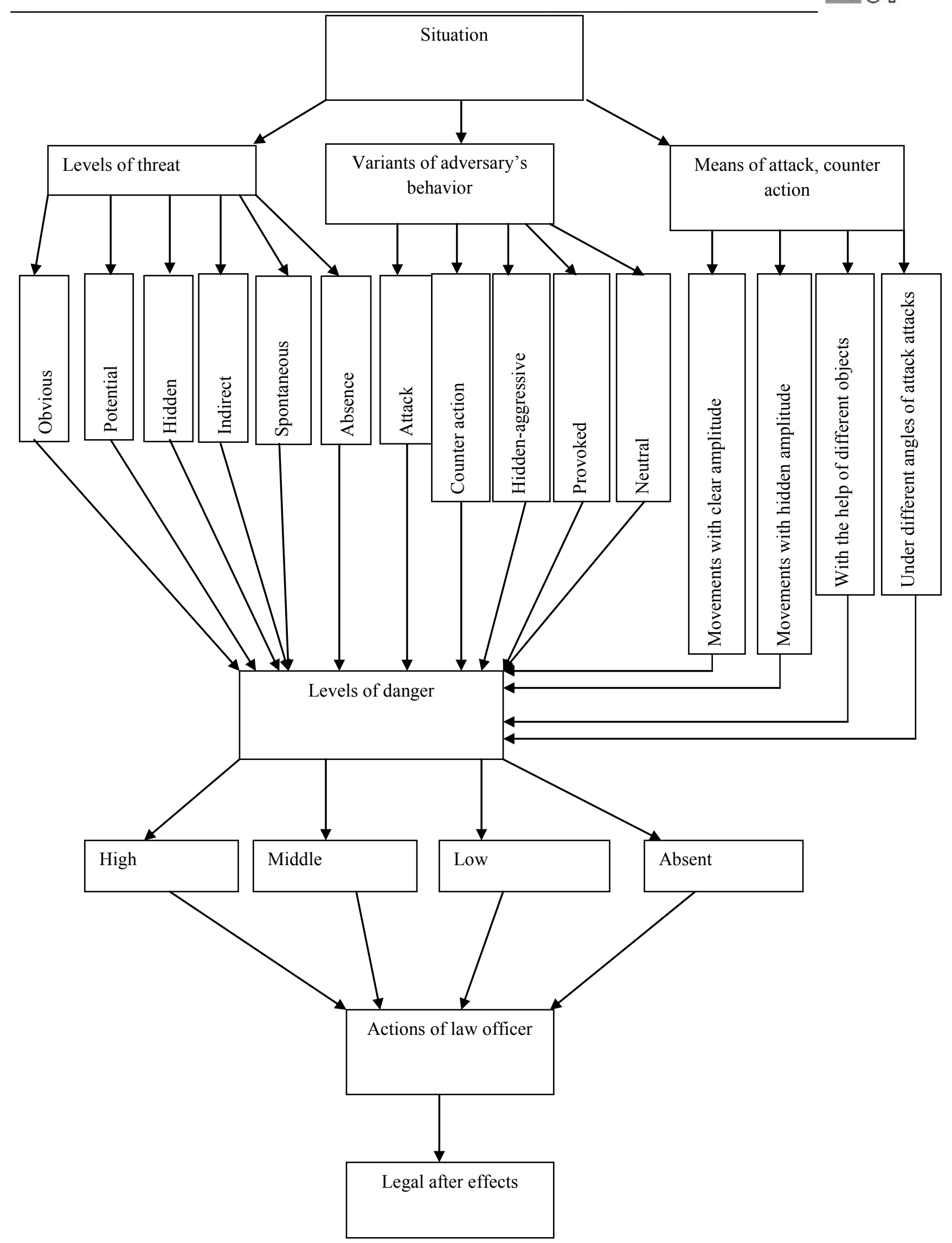

Fig. 1 Variants if levels of threat and danger according to situations 


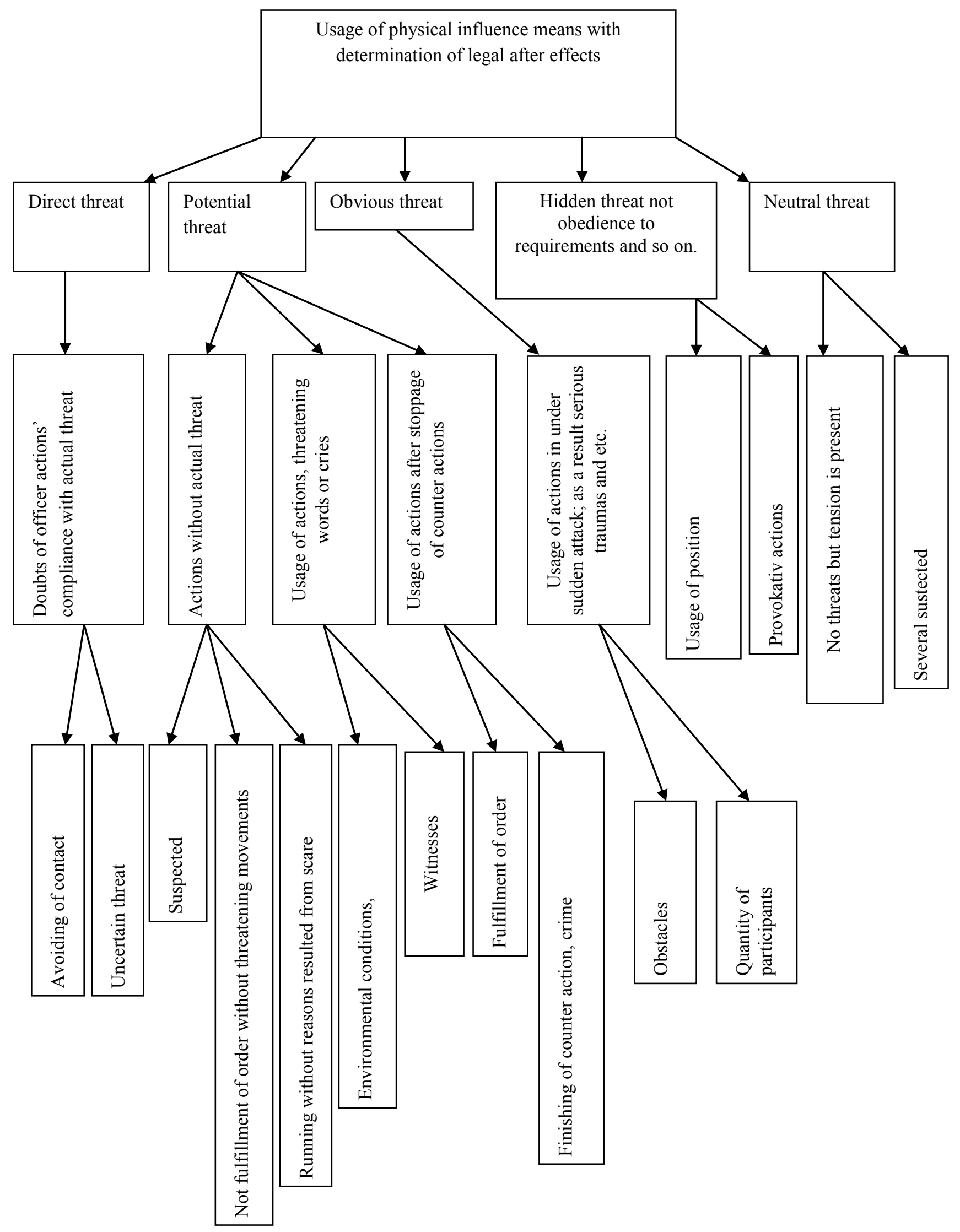

Fig.2. Determination of legal after effects in conditions of danger of different levels 
Training based on simulation of situations is a complex process, which stipulates coordination, accordance of actions of all participants. Purpose of simulation shall be compulsory determined. General tasks are set in compliance with this purpose. Then specific functional tasks for every participant are formulated. It should be noted that even insignificant deviation from actual actions' or behavioral criteria (which are simulated) can prevent from achieving of purpose. After simulation of situational episode brief conclusions about achievement of purpose are made. Simulation of situational episodes it is purposeful to conduct in conditions of different threats; it is necessary to create sudden situations with aggressiveness of different level. With it all participants shall not be previously informed about following actions. It can be simultaneous demonstration of situational episode. Besides, changes, in case of trainee's untimely actions, are possible. I.e. there is free transition to other motion action, manners and so on. With simulation of situations it is necessary to avoid excessive fantasy. For simulation situations, which happened in reality, can be used [2].

After seven days special training course we conducted experiment, in which 30 persons participated (control group - CG) and 30 persons - experimental group (EG). The participants were in equal conditions: during period of testing every of them was put three questions. The questions were not repeated; participants had no opportunity to know them beforehand. In total we prepared 90 questions, equal for both groups. With it we used method of pedagogic testing [3].

Simulation of episodes of sudden extreme situations took place in gyms and conference halls. We chose 10 episodes. All they were unknown for participants. Every participant took part only in one episode. With simulation w used method of scientific experiment [4].For example: situations simulated behind curtains. With its opening participant appears. In front of him a person lies; the second bent over him, the third runs away. Participant is offered maximum 3 sec. for solution of this task.

In other case, by composed previously scenario-dialogue (violator and his victim) conflict was played. Deviation from scenario was admitted and at some moment play became "free". But it continued without application of physical force. At the height of dialogue the third party intervened - law officer, who arrived at the place of event. "Victim" obeyed orders of law officer. Behavior of violator was of chaotic character. Participant had to pass situation into peaceful manner. We evaluated: sureness of behavior; tone of speech; tactic techniques; creative approach to the solution of problem (initiative); manner of movements; application of improvised means, position. All ready made combinations of actions started suddenly for participants and order of positions' demonstration was rather variable. With it participant of experiment (or other persons) had to timely respond to the moment of appearing of potential or direct threat. Further progressing of situation was stopped by one of experts.

At the same time trainees put brief characteristics to own actions from the point of adequacy in respect to manifested threat. Criteria of task's fulfillment were: time for perception of situation and threat; time for taking decision; time for taking certain position; correctness of respond to threats; own actions and actions, which could result in certain legal after effects.

Evaluation of correctness of perception and adequacy of analysis was carried out by commission of three experts: two specialists in physical training and tactics and specialists lawyer. Evaluation system includes: 1. Adequacy of actions for taking decision and level of threat; 2. Time of execution; 3. Evaluation of actions in respect to degree of threat; 4. Positional location;, preventing from aggressive adversary's actions, readiness for actions, own safety.; 5. Legal characteristic of every certain moment: what threat can appear in respect to legal field. 
Level of adequacy of law officers' respond to threats

\begin{tabular}{|c|c|c|c|c|c|c|c|c|c|c|c|c|}
\hline \multirow[b]{2}{*}{ Tasks } & \multicolumn{2}{|c|}{$\begin{array}{c}\text { Adequacy } \\
\text { (correctness) } \\
\text { of motion } \\
\text { behavior }\end{array}$} & \multicolumn{2}{|c|}{ Confidence } & \multicolumn{2}{|c|}{$\begin{array}{c}\text { Emotions } \\
\text { manners of } \\
\text { behavior and so } \\
\text { on. }\end{array}$} & \multicolumn{2}{|c|}{ Confidence } & \multicolumn{2}{|c|}{$\begin{array}{l}\text { Legal after } \\
\text { effects }\end{array}$} & \multicolumn{2}{|c|}{ Confidence } \\
\hline & $\begin{array}{c}\text { CG } \\
(\mathbf{n}=\mathbf{3 0} \\
), \\
\mathbf{X} \pm \mathbf{m}\end{array}$ & $\begin{array}{c}\mathbf{E G} \\
(\mathbf{n}=\mathbf{3 0} \\
), \mathbf{X} \pm \\
\mathbf{m}\end{array}$ & $\mathbf{t}$ & $\mathbf{P}$ & 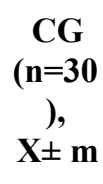 & $\begin{array}{c}\text { EG } \\
(\mathbf{n}=\mathbf{3 0}) \\
\mathbf{X} \pm \mathbf{m}\end{array}$ & $\mathbf{t}$ & $\mathbf{P}$ & $\begin{array}{c}\text { CG } \\
(\mathbf{n}=\mathbf{3 0} \\
) \\
\mathbf{X} \pm \mathbf{m}\end{array}$ & $\begin{array}{c}\underset{(\mathbf{E G}}{(\mathbf{n}=30} \\
\mathbf{X} \pm \mathbf{m}\end{array}$ & $\mathbf{t}$ & $\mathbf{P}$ \\
\hline $\begin{array}{l}\text { Testing } \\
\text { (90question } \\
\text { s) }\end{array}$ & $\begin{array}{c}13.5 \pm \\
0.64\end{array}$ & $\begin{array}{c}64.8 \pm \\
0.98\end{array}$ & $\begin{array}{c}43.82 \\
9\end{array}$ & $\begin{array}{c}<0.00 \\
1\end{array}$ & $\begin{array}{l}6.3 \pm \\
0.28\end{array}$ & $\begin{array}{c}53.1 \pm 1 \\
3\end{array}$ & $\begin{array}{c}35.1 \\
9\end{array}$ & $\begin{array}{c}<0.00 \\
1\end{array}$ & $\begin{array}{c}35.1 \pm \\
0.92\end{array}$ & $\begin{array}{c}54.9 \pm \\
1.1\end{array}$ & 3.81 & $\begin{array}{c}<0.00 \\
1\end{array}$ \\
\hline $\begin{array}{l}\text { Actions in } \\
\text { simulation } \\
\text { of extreme } \\
\text { situation } \\
\text { (30 } \\
\text { episodes) }\end{array}$ & $\begin{array}{l}6.9 \pm \\
0.35\end{array}$ & $\begin{array}{c}20.1 \pm \\
0.68\end{array}$ & $\begin{array}{c}17.26 \\
0\end{array}$ & $\begin{array}{c}<0.00 \\
1\end{array}$ & $\begin{array}{l}3.6 \pm \\
0.26\end{array}$ & $\begin{array}{c}19.2 \pm 0 \\
57\end{array}$ & $\begin{array}{c}24.9 \\
0\end{array}$ & $\begin{array}{c}<0.00 \\
1\end{array}$ & $\begin{array}{c}12.9 \pm \\
0.39\end{array}$ & $\begin{array}{l}19.5 \pm \\
0.71\end{array}$ & $\begin{array}{c}8.14 \\
8\end{array}$ & $\begin{array}{c}<0.00 \\
1\end{array}$ \\
\hline
\end{tabular}

Effectiveness of tasks' solution by EG members in respect to CG is given in table 1.

It should be noted that $10 \%$ of participants from EG were not in time with fulfillment of tasks, while in CG $40 \%$.

\section{Discussion}

The worked out by us methodic is a new project in professional training. Scientific novelty is that for the first time we used new algorithm of law officers' training, for formation of knowledge and skills in practical functioning in extreme situations. We proved experimentally effectiveness of actions in time, recognition and perception of threat, choosing of actions and responding to danger.

In experimental group perception time of threat from the moment of its appearing was in average 1.5-2 sec. Time for taking decision - 1-1.5 sec. Time of taking position coincides with time of taking decision and is approximately 1-2 sec. In CG time range was wider - from У КГ 1 to $7 \mathrm{sec}$. It witnesses about different perception of threatening actions. Some trainees showed certain delay in perceiving of actions' combinations and evaluation. Tim for determination of situation was delayed or excessively accelerated. Such response was registered because of seeking of threat's degree or as too early in respect to event itself (taking position). In experiment it was noted that with every following participation in demonstration of motion and behavioral combinations most of trainees improved their indicators by all items. So, method of fulfillment of experiment, selection of means were approximated to academic process. If during fulfillment of first two-three tasks in EG indicators of effectiveness were 60-65\%, in second - (CG) 20 - 23\%, then by the end of all tasks indicators significantly improved. Adaptation of participants to experiment's conditions also played important role. At the beginning of test we observed certain psychological tension and there was a trend to reduction of indicators.

Results of the research are in accordance with experts' opinion (V.V. Bondarenko, Yu.V. Denisenko, L.N. Kucheriaviy).

Conclusions:

Our researches showed that effectiveness of cadets' training to special physical and tactic fitness increases significantly with purposeful formation of knowledge and skills in recognitions of different by level threats. At first stage of training cadets (law officers) had to master knowledge about gradations of different situations (typical and not standard), moments of threats' appearing, their consequences, in determination of differentiating factors. Then the mastered knowledge is trained to level of skills. I.e. for short time (in seconds) threat and its after effects are determined. After it, it is necessary to master variants of responding to different threats' manifestations. At second stage of training some cadets simulate different levels of threat and other - respond to them. At third stage sudden threat is simulated, to which it is necessary to adequately respond. Fulfillment is restricted by time.

It was determined that in process of simulated situations of conflict with aggressive adversary cadets substantially increased adequacy of responding to appeared threat during fulfillment (within legal frames). Recognition of aggressiveness level was determined by manifested manners of adversary, his emotions, motivations, motion 
behavior during 2-3 seconds. Development of attention, ability to orient, to perceive, to be ahead in actions is also important.

\section{References:}

1. Belkin R.S. Teoriia i praktika sledstvennogo eksperimenta [Theory and practice of investigative experiment], Moscow, Graduate School of the USSR Ministry of Internal Affairs, 1959, 169 p. (In Russian)

2. Plisko V. I., Nosko M. O. Vikoristannia zakhodiv fizichnogo vplivu z taktichnim osmislenniam situacii vidpovidno do stupenia zagrozi [The use of physical impact of tactical understanding of the situation according to the degree of threat], Chernihiv, 2010, 284 p. (In Ukrainian)

3. Plisko V.I. Formirovanie gotovnosti professionala $k$ deiatel'nosti $v$ usloviiakh, opasnykh dlia zhizni: na materialakh sub"ekt-sub"ektnoj deiatel'nosti [Formation of readiness to professional activity in conditions hazardous to life on the materials the subject of subjective activity], Kiev, Scientific World, 2002, 304 p. (In Russian)

4. Davydov V.V. Psikhologicheskij slovar' [Psychological dictionary], Moscow, 1983, pp. 370. (In Russian)

5. Khramovich M.A. Nauchnyj eksperiment, ego mesto i rol'v poznanii [Scientific experiment, its place and role in cognition], Minsk, BU V.I. Lenin Publ., 1972, 230 p. (In Russian)

6. Banakh S.M., Bulachek V.R., Viniarchuk I.S., Josipiv Iu.R. Taktiko-special'na pidgotovka pracivnikiv OVS Ukraini [Tactical and special training of policemen of Ukraine], Lviv, LvDUVS, 2011, 300 p. (In Ukrainian)

7. Shojgu Iu.S. Psikhologiia ekstremal'nykh situacij dlia spasatelej i pozharnykh [Psychology of extreme situations for the rescuers and firefighters], Moscow, Meaning, 2007, 319 p. (In Russian)

8. Anufriiev M. I, Butov S. Ye, Gida O. F., Reshko S. M. Osnovi special'noi fizichnoi pidgotovki pracivnikiv OVS [Fundamentals of special physical training police officers], Kiev, 2003, 338 p. (In Ukrainian)

9. Babenko V. G., Popov O. V., Ianko I. V. Zakhodi fizichnogo vplivu [Measures of physical restraint], Kiev, 2001, 24 p. (In Ukrainian)

10. Zakorko I. P. Special'na fizichna pidgotovka u vishchikh navchal'nikh zakladakh MVS Ukraini z urakhuvanniam individual'nikh osoblivostej motoriki kursantiv. Kand.diss. [Physical training in higher educational establishments of Ukraine, taking into account the individual characteristics of motor cadets. Cand. Diss.], Kiev, 2001, 300 p. (In Ukrainian)

11. Smirnov B.A., Dolgopolova E.V. Psikhologiia deiatel'nosti v ekstremal'nykh situaciiakh [Psychology of activity in extreme situations], Kharkov, Humanitarian Center Publ., 2007, 276 p. (In Russian)

12. Yevsiukov O.P. Ekstremal'na psikhologiia [Extreme psychology], Kiev, Ltd. "August Trade", 2007,502 p. (In Ukrainian)

13. Bondarenko V. V. Model' iakostej pracivnika milicii, iaka nadaie jomu perevagu $\mathrm{v}$ umovakh nespodivanogo zitknennia z ozbroienim suprotivnikom [Model properties of militia worker, which gives him an advantage in terms of unexpected collision with an armed enemy]. Visnik Chernigivs'kogo derzhavnogo pedagogichnogo universitetu, 2010, no.81, pp. 136 - 140. (In Ukrainian)

14. Lefterov V.O. Osobistisno-profesijnij rozvitok fakhivciv ekstremal'nikh vidiv diial'nosti. Dokt.diss. [Personally professional development of specialists of extreme activities. Dokt.diss.], Kharkov, 2008, 37 p. (In Ukrainian)

15. Artamanova G.K., Mameeva I.S. Organizacionnye i pravovye formy i metody deiatel'nosti po sozdaniiu normativno-pravovoj bazy v sfere obespecheniia pozharnoj bezopasnosti [Organizational and legal forms and methods of work to create the legal framework in the field of fire safety]. Vestnik Sankt-Peterburgskogo universiteta GPS MChS Rossii. 2012, no.2, pp. 97-102. (In Russian)

16. Kartashov V.N. Iuridicheskaia tekhnika, taktika, strategiia i tekhnologiia [Legal technique, tactics, strategy and technology (to the question of the relationship)]. Problemy iuridicheskoj tekhniki, 2005, no.1, pp. 111. (In Russian)

17. Kazakov Iu.N. Psikhologo-akmeologicheskaia sushchnost' ekstremal'nykh situacij v deiatel'nosti municipal'nykh sluzhashchikh [Psychological akmeological essence of extreme situations in the work of municipal employees], Municipal'naia sluzhba: pravovye voprosy, 2008, no.4, pp. 20-26. (In Russian)

18. Derkach A.A., Zazykin V.G. Professionalizm deiatel'nosti v osobykh i ekstremal'nykh usloviiakh [Professionalism activity in special and extreme conditions], Moscow, RAGS, 1998, 178 p. (In Russian)

19. Dmitrenko I.A. Ekologichne pravo Ukraini [Environmental Law of Ukraine], Kiev, Inter Yurinkom, 2001,352 p. (In Ukrainian)

20. Strekozov V.G. Voennoe pravo [Military law], Moscow, 2004, 640 p. (In Russian)

21. Belur J., Tilley N., Osrin D., Daruwalla N., Kumar M., Tiwari V. Police investigations: discretion denied yet undeniably exercised. Policing and Society. 2014, vol.1, no.24, pp. 45-55. http://dx.doi.org/10.1080/10439463.2013.878343.

22. Dean G., Fahsing I.A., Glomseth R., Gottschalk P. Capturing knowledge of police investigations: towards a research agenda. Police Practice and Research. 2008, vol.9, no.4, pp. 341-355. http://dx.doi.org/10.1080/15614260802354650.

23. Dean G., Fahsing I.A., Gottschalk P. Profiling police investigative thinking: A study of police officers in Norway. International Journal of the Sociology of Law. 2006, vol.34, no.4, pp. 221-228. http://dx.doi.org/10.1016/j.ijsl.2006.09.002. 
24. Glomseth R., Gottschalk P., Solli-Sæther H. Occupational culture as determinant of knowledge sharing and performance in police investigations. International Journal of the Sociology of Law. 2007, vol.35, no.2, pp. 96107. http://dx.doi.org/10.1016/j.ijsl.2007.03.003.

25. Heinonen A., Ellonen N. "Crime or not?" - police officers' perceptions of disciplinary violence, its criminalisation and its investigation. Policing and Society. 2014, vol.1, no.19, pp. 56-62. http://dx.doi.org/10.1080/10439463.2014.989151.

26. Royds D. Death Investigation. A Handbook for Police Officers. Australian Journal of Forensic Sciences. 2002, vol.34, no.2, pp. 93-94. http://dx.doi.org/10.1080/00450610209410843.

27. Ryan B.J. What the Police are Supposed to Do: Contrasting Expectations of Community Policing in Serbia. Policing and Society. 2007, vol.17, no.1, pp. 1-20. http://dx.doi.org/10.1080/10439460601124106.

28. Semukhina O. Public assistance of police during criminal investigations: Russian experience. Police Practice and Research. 2014, vol.1, no.20. pp. 67-73. http://dx.doi.org/10.1080/15614263.2014.949263.

29. Thomassen G. Investigating Complaints against the Police in Norway: An Empirical Evaluation. Policing and Society. 2002, vol.12, no.3, pp. 201-210. http://dx.doi.org/10.1080/10439460290018445.

30. Walker S. The neglect of police unions: exploring one of the most important areas of American policing. Police Practice and Research. 2008, vol.9, no.2, pp. 95-112. http://dx.doi.org/10.1080/15614260802081253. 
Information about the authors:

Radzievskiy R. M.: http://orcid.org/0000-0002-9600-7383;

vikastar2002@ukr.net; Chernigov National Pedagogical University;

Getman Polubotka str. 53, Chernigov, 14013, Ukraine.

Plisko V.I.: http://orcid.org/0000-0001-7222-2057; vikastar2002a@ukr. net; Chernigov National Pedagogical University; Getman Polubotka str. 53, Chernigov, 14013, Ukraine.

Cite this article as: Radzievskiy R.M., Plisko V.I. Law enforcers recognition level emerging threats based on physical appearance and behavior signs the enemy. Physical education of students, 2015, no.1, pp. 50-59. http://dx.doi.org/10.15561/20755279.2015.0108

The electronic version of this article is the complete one and can be found online at: http://www.sportpedu.org.ua/html/arhive-e.html

This is an Open Access article distributed under the terms of the Creative Commons Attribution License, which permits unrestricted use, distribution, and reproduction in any medium, provided the original work is properly cited (http:// creativecommons.org/licenses/by/3.0/deed.en).

Received: 15.11 .2014

Accepted: 27.12.2014; Published: 30.12.2014 